\title{
Advances in Enzyme Assisted Extraction of Natural Products
}

\section{Xian Cheng ${ }^{1, a}$, Liangwu Bi ${ }^{1,2, b^{*}}$, Zhendong Zhao ${ }^{1,2, c}$ and Yuxiang Chen ${ }^{1,2, d}$}

${ }^{1}$ Institute of Chemical Industry of Forest Products, CAF; National Engineering Lab. for Biomass Chemical Utilization; Key and Open Lab. of Forest Chemical Engineering, SFA; Key Lab. of Biomass Energy and Material, Nanjing, China

\author{
${ }^{2}$ Research Institute of Forestry New Technology, CAF, Beijing, China

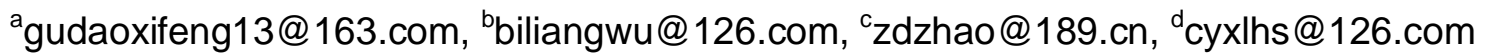

\begin{abstract}
Keywords: enzyme assisted extraction; natural product; biotechnology
\end{abstract}
Abstract. This review gives a summary about the application of enzyme assisted extraction in natural products, especially, the mechanism of enzyme assisted extraction and its further improvement. The target of this review is to find the potential value of biotechnology for industrial application.

\section{Introduction}

In recent years, natural products have been widely used in food, medicinal and chemical industries due to their biological activities. The constituents of bioactive products in natural plants are complex, but the contents are too low. Traditional methods for extraction and purification possess many disadvantages, which limited the full use of natural products. At the same time, it is difficult to apply traditional methods in large-scale industrial production. So, it is needed to improve the method of extraction and purification.

Many extraction methods available for recovery of natural products from herbs have been studied with the development of chemical technology. Organic solvent extraction which based on the principle that the solvent diffuses in the matrix and dissolves the soluble compounds is the most widely used method ${ }^{[1]}$. Many studies have focused on the optimization of extraction parameters, such as solvent type, solvent to solid ratio, particle size, temperature and extraction time in order to increase the yield. However, major disadvantages of those methods have not been solved. 1) The large consumption of organic solvents or water in extraction step. 2) The high energy required for the separation of solute. 3) The co-extraction of undersirable components. 4) The possible degradation of thermo-sensitive compounds such as carotenoids ${ }^{[2]}$. It is necessary to identify and develop new efficient extraction processes to utilize the natural products present in plants. Recently, ultrasound assisted $^{[3]}$, microwave assisted ${ }^{[4]}$, supercritical fluid extraction ${ }^{[5]}$, enzyme assisted ${ }^{[6]}$ and extraction at high pressure have been successfully used in many applications for extraction of natural products.

Enzyme assisted technology has attached research interest especially due to several advantages. Enzymes are highly efficient and specific ${ }^{[7,8]}$. Enzyme assisted extraction can be an alternative method due to mild environmental conditions, without large amount of undesired products generally and has lower impact on the environment ${ }^{[9]}$. This review describes the advances of enzyme assisted extraction of natural products simply. 1) It is a high bioactive yielding technology by which cell walls are broken down and desired bioactive products are released. 2) It also removes the unnecessary components from cell walls, the barriers of water solubility and insolubility to improve the transparency of system. 3) It offers the benefits of high catalytic efficiency and preserves original efficacy of the natural products to a high degree ${ }^{[6]}$.

\section{The types and characteristics of enzyme}

Enzymes can be derived from bacteria, fungi, animal organs, or vegetable extracts and fruits. They are classified into the following types: hydrolyzing enzymes, oxidation-reduction enzymes, ligases, group trasnsfer enzymes, desmolases, isomerizing enzymes, and carboxylation enzymes. Based on their catalytic property of catalyzing definite reactions, a particular enzyme acts on a specific substrate. Enzymes which were applied in the extraction of natural products from plants usually were shown in Table 1. Enzymes are ideal catalysts that can assist in the extraction of complex bioactive 
compounds of natural origin by degrading the cell walls and membranes. Consequently, they increase cell wall permeability and thus, higher extraction yields of bioactive compounds are achieved ${ }^{[10]}$.

\section{Table 1 The application of enzyme in the extraction for natural products from plants}

\begin{tabular}{cccccc}
\hline & & \multicolumn{4}{c}{ application } \\
\cline { 3 - 6 } enzyme & enzyme composition & product & source & $\begin{array}{c}\text { maximu } \\
\mathrm{m} \\
\text { nyeld \% }\end{array}$ & refs \\
\hline \multirow{3}{*}{ cellulase } & exo-1,4- $\beta$ - $D$-glucanase, & oligosacchiaride & rice bran & 39.9 & {$[11]$} \\
& $1,4-\beta-D$-glucanase, & lignans & flax & 0.407 & {$[12]$} \\
& $1,4-\beta$-glucosidase & anthocyanins & saffron & 0.67 & {$[13]$} \\
pectinase & pectin hydrolase, pectin & sugar & grapefruit peel & 0.638 & {$[14]$} \\
& lyase, pectin esterase & starch & cassara & 45.6 & {$[15]$} \\
hemicellulase & quercetin & onion & 75 & {$[16]$} \\
& mannanase, xylanase & colourant & pitaya & 83.5 & {$[17]$} \\
\hline
\end{tabular}

\section{The breakdown of cell walls by enzyme}

The breakdown of cell walls is the critical step of extraction for many bioactive compounds existing inside of cell walls. Enzyme assisted extraction is based on the ability of enzymes to hydrolyze cell wall components and disrupt the structural integrity of the plant cell wall (As was shown in Fig.1.), under mild process conditions, thereby allowing the efficient extraction and release of the bioactive compounds ${ }^{[18,19]}$. When enzymes and substrates bind together, the shape of the enzyme molecule changes into an optimum fit for the interaction between enzyme and substrate. The change in the shape of could result in stress and strain on the substrate causing the bonds to break thereby promoting the reaction. When the substrate concentration is high, the addition of the enzyme can enhance the rate of reaction, till the substrate concentration becomes limiting. There is a direct proportionality between the rate and the substrate concentration until the enzyme concentration becomes limiting ${ }^{[20]}$. In each study of enzyme assisted extraction, the operational condition such as: temperature of reaction, time of extraction, $\mathrm{pH}$ of system, enzyme concentration, particle size of substrate. The process of enzyme assisted extraction method for the natural products was shown in fig.2.All the results of studies show that enzyme assisted extraction lead to a reduction in extraction in extraction time and solvent volume in addition to the increased yield and quality of product.

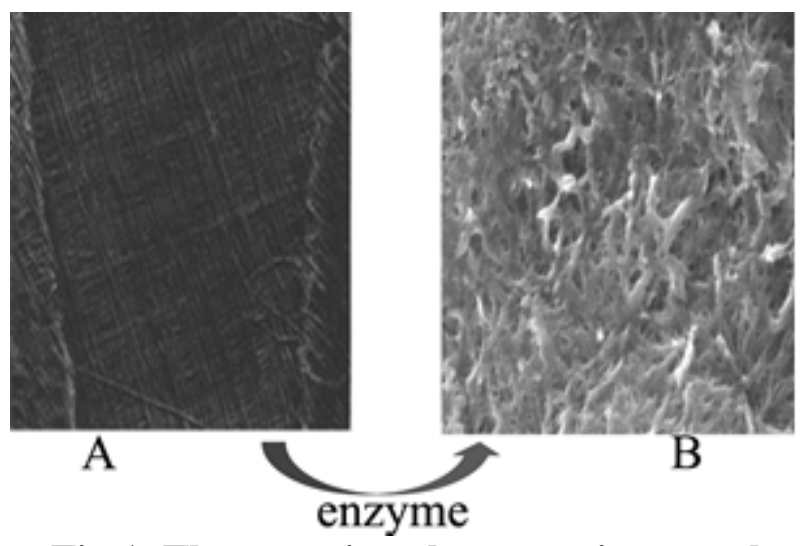

Fig.1. The scanning electron micrographs

A: cell wall of plant without treatment;

B: cell wall of plant which was treated with enzyme 


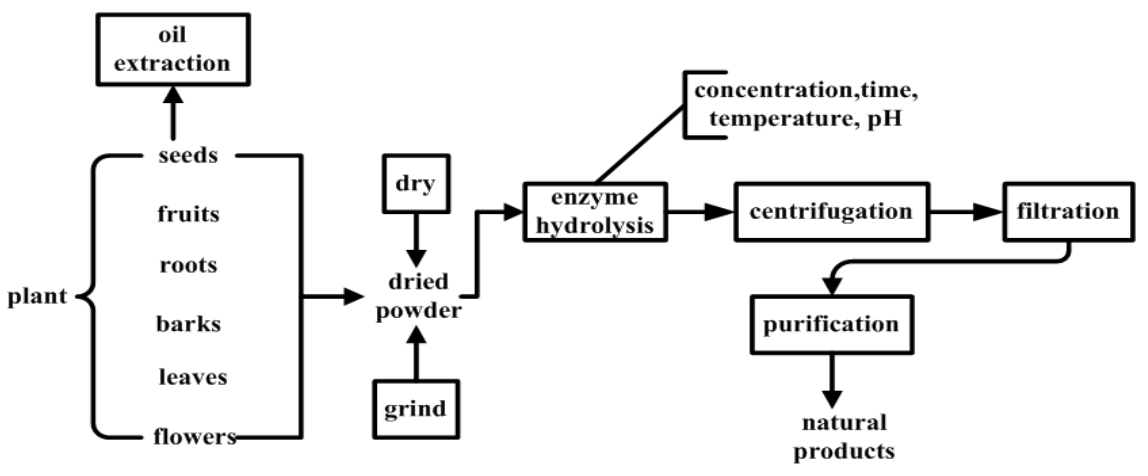

Fig.2. The process of enzyme assisted extraction method for the natural products

\section{The improvement of system' transparency and products' quality}

The constituents of bioactive products in natural plants are complex, they mix with protein, pectin, starch, and cellulose in cells. Those impurities not only decrease the extraction yields of natural products, but also reduce the transparency of system. Therefore, the quality of products was hard to be improved. When appropriate enzyme was added into the system of extraction, it could assist in breaking the complex bonding between pectin and protein in cells. The transparency of system and the quality of product could increase significantly. Zhang treated blackberry juice with the mixture of pectinase and multiplexed peitinase preparation to study the clarification. The results show that the optimal enzymatic treatment condition were as follow: $0.13 \%$ enzyme was add and the ration of two enzyme was $1: 1$.T he maximal juice yield was $79.5 \%$, the anthocyanins content of the juice was $676.24 \mathrm{mg} \cdot \mathrm{L}^{-1[21]}$.

Some compounds exist in the plants have low bioactive or no bioactive, but their chemical structure might be similar to the target products. Special enzyme which added in the extraction system could change their chemical structure into target structure. This feature of enzyme results in the improvement of products' quality. Enzymes are also used in various organic reactions for specific purposes such as cleavage of ester bonds, separation of racemic mixtures to obtain a single optically active compound, and cleavage of double bonds. Ginsenosides are the principle components responsible for the pharmaceutical activities of ginseng. Some minor ginsenosides( $\left.R h_{2}\right)$ exhibited various biological and pharmacological activities, including anti-tumor, immune-modulatory, anti-inflammatory and anti-aging effects. These minor ginsenosides, however, exsited in very low content or even did not naturally present in ginseng. Jin treated some high-content ginsenosides ( $\mathrm{Rb}$, $\mathrm{Rc}, \mathrm{Rd})$ which had similar structure as $\mathrm{Rh}_{2}$ with glycoside hydrolases. After treatment with enzyme, the yield of transformation from high-content ginsenosides to $\mathrm{Rh}_{2}$ approached $60 \%$. This result is 500 - 700 timers that of extraction from ginseng without enzyme.

\section{The combination of enzyme and ultrasound}

Recently, enzyme was combined with ultrasound, microwave and supercritical fluid for improving extraction. The combination of enzyme and ultrasound has been studied to applied in many plants for the extraction of natural product. Ultrasonic wave can improve the capability of enzyme. At the same time, it makes the enzyme spreading evenly ${ }^{[22]}$. Low ultrasonic power would not inactivate enzyme. Vergara-Barberan improved protein extraction from olive leaves with the assist of enzyme and ultrasound. the total protein amount comprised was between 1.87 and $6.64 \mathrm{mg} \cdot \mathrm{g}^{-1[23]}$. Wang made the extraction of isoflavones from soy residue with ultrasound and cellulase both together or each separately ${ }^{[24]}$. The results show that both ultrasonic and cellulase can promote the extraction yield, and when making the treatment with ultrasonic and cellulase together, tht amount of isoflavones approaches to $8.34 \mathrm{mg} \cdot \mathrm{g}^{-1}$, the yield increased by $51.83 \%$, compared with traditional methods. Therefore, the developed enzyme-assisted extraction method has shown a faster extraction, high recovery and reduced solvent usage with respect to the extraction without enzyme ${ }^{[25]}$. 


\section{Conclusion}

Enzyme assisted extraction of natural product from plants leads to a reduction in extraction time and organic solvent in addition to the increased transparency of system, yield and quality of product. However, enzyme assisted extraction has potential commercial and technical limitations ${ }^{[10]}$. 1) Enzymes are relatively expensive for large industrial production. 2) Available enzyme cannot break down the plant cell walls completely. 3) Enzyme assisted extraction is not always feasible to be applied in industrial scale because enzymes behave was limited by environmental conditions rigidly. The above limitations were needed to be solvent in order to make full use of enzymes' potential value in the exploitation and utilization of natural products.

\section{Acknowledgement}

The authors would like to thank the support from 948 Project of State Forestry Administration (2011-4-01).

\section{Reference}

[1]C. Tzia, G. Liadakis, Extraction optimization in food engineering, CRC Press, 2003.

[2]L. Wang, C.L. Weller, Trends in Food Science \& Technology 17 (2006) 300-312.

[3]S. Albu, E. Joyce, L. Paniwnyk, J. Lorimer, T. Mason, Ultrasonics Sonochemistry 11 (2004) 261-265.

[4]Y. Yuan, D. Macquarrie, Carbohydr. Polym. 129 (2015) 101-107.

[5]R.N. Carvalho, L.S. Moura, P.T. Rosa, M.A.A. Meireles, The Journal of Supercritical Fluids 35 (2005) 197-204.

[6]Y.J. Jeon, W. Wijesinghe, S.K. Kim, Handbook of Marine Macroalgae: Biotechnology and Applied Phycology (2011) 221-228.

[7]J. Fleurence, L. Massiani, O. Guyader, S. Mabeau, Journal of applied phycology 7 (1995) 393-397.

[8]J. Linnell, H.M. Mackenzie, J. Wilson, D. Matthews, Journal of clinical pathology 22 (1969) $545-550$.

[9]L. Shen, X. Wang, Z. Wang, Y. Wu, J. Chen, Food Chem. 107 (2008) 929-938.

[10]M. Puri, D. Sharma, C.J. Barrow, Trends in biotechnology 30 (2012) 37-44.

[11]J. Patindol, L. Wang, Y.J. Wang, Journal Of Food Science 72 (2007) C516-C521.

[12]S. Renouard, C. Hano, C. Corbin, O. Fliniaux, T. Lopez, J. Montguillon, E. Barakzoy, F. Mesnard, F. Lamblin, E. Laine, Food Chem. 122 (2010) 679-687.

[13]L. Lotfi, A. Kalbasi-Ashtari, M. Hamedi, F. Ghorbani, J. Food Drug Anal. 23 (2015) 210-218.

[14]M.R. Wilkins, W.W. Widmer, K. Grohmann, R.G. Cameron, Bioresource Technology 98 (2007) 1596-1601.

[15]R.W. Palmer, N.A. Rivers-Moore, Onderstepoort Journal Of Veterinary Research 75 (2008) 299-314.

[16]I.S. Choi, E.J. Cho, J.H. Moon, H.J. Bae, Food Chem. 188 (2015) 537-542.

[17]R.M. Schweiggert, M.G. Villalobos-Gutierrez, P. Esquivel, R. Carle, Eur. Food Res. Technol. 230 (2009) 269-280.

[18]L. Gardossi, P.B. Poulsen, A. Ballesteros, K. Hult, V.K. Švedas, Đ. Vasić-Rački, G. Carrea, A. Magnusson, A. Schmid, R. Wohlgemuth, Trends in biotechnology 28 (2010) 171-180.

[19]M. Pinelo, A. Arnous, A.S. Meyer, Trends in Food Science \& Technology 17 (2006) 579-590.

[20]H. Sowbhagya, V. Chitra, Critical reviews in food science and nutrition 50 (2010) 146-161.

[21]L. Zhang, J. Zhou, H. Liu, K. Huang, Z. Gu, Transactions of the Chinese Society of Agricultural Engineering 26 (2010) 372-376.

[22]V.G. Yachmenev, E.J. Blanchard, A.H. Lambert, Ind. Eng. Chem. Res. 37 (1998) 3919-3923.

[23]M. Vergara-Barberan, M.J. Lerma-Garcia, J.M. Herrero-Martinez, E.F. Simo-Alfonso, Food Chem. 169 (2015) 28-33. 
[24]Wanneng Wang, Xuejun Quan, Tianjian Lu, Journal of Chemical Engineering of Chinese Universities 21 (2007) 370-374.(in Chinese)

[25]M.H. Entezari, C. Petrier, Appl. Catal. B-Environ. 53 (2004) 257-263. 